\title{
HISTORICAL GEOGRAPHY IN THE CONTEXT OF THE DIDACTICS OF HISTORY IN UNDERGRADUATE EDUCATION: AN EXAMPLE OF USE OF MATTHIAS BEL'S WORK VEDOMOSTI \\ [HISTORICKA GEOGRAFIE V KONTEXTU VYSOKOSKOLSKE VYUKY HISTORIE: PRIKLAD VYUZITI DILA VEDOMOSTI MATEJE BELA]
}

\section{Tatana Souckova}

doi: 10.18355/PG.2020.9.1.7

\begin{abstract}
The aim of the paper is to analyse the possibilities of using a unique historical source from the $18^{\text {th }}$ century called Notitia Hungariae Novae Historicogeographica from Matthias Bel in undergraduate education of history and history in combination (teacher training). Two methodological approaches to the material are parallelly being examined. The first one represents general didactics of the higher education and the second one shows specific methods used in historical research. Both approaches are combined and in order to characterise the undergraduate education of history and its goals. Moreover, several examples of students' works based on interpretation of Bel's Vědomosti are shown.
\end{abstract}

Key words

Matthias Bel, didactics of history, undergraduate education, methodology, historical geography, environmental history, local and regional history

\section{Anotace}

Cílem textu je analyzovat možnosti využití jedinečného historického pramene Notitia Hungariae Novae Historico-geographica (Vědomosti), který vznikl v 18. století a jehož autorem je uherský polyhistor Matěj Bel, v rámci vysokoškolské výuky oboru historie a učitelství akademických předmětů (historie v kombinaci). Příspěvek propojuje dva metodické přístupy, obecně didaktický a historický. Obě hlediska jsou vzájemně kombinována za účelem charakteristiky vysokoškolské výuky historie, včetně rozboru příslušných vzdělávacích cílů. $\mathrm{V}$ neposlední řadě jsou uvedeny konkrétní př́íklady studentských prací, v nichž byly využity různé formy interpretace Belových Vědomostí.

\section{Klíčová slova}

Matěj Bel, didaktika historie, terciární vzdělávání, metodika, historická geografie, environmentální historie, regionální dějiny

\section{Úvod}

Dílo Matěje Bela je v současnosti ve slovenském akademickém prostředí diskutovaným tématem, a to zejména v souvislosti s publikováním kritických edic jeho nejrozsáhlejšího a nejznámějšího díla Historicko-zeměpisné 
vědomosti o novém Uhersku (v latinském jazyce Notitia Hungariae Novae Historico-geographica, dále jako Védomosti). Nově bylo pod patronátem Kysuckého muzea v Čadci vydáno pět svazků slovensko-latinského překladu popisu následujících stolic: Trenčínská (2013), Liptovská (2014), Oravská (2015), Turčanská (2016), Zvolenská (2017) a Těkovská (2019).

V souvislosti s edicemi a jejich využitím pro další výzkum je akcentována především mnohovrstevnatost Belova díla a tím i rozličné možnosti jeho využití v intencích různých vědních oborů. Paleta je skutečně široká, kromě historie zahrnuje také dějiny umění, geografii, filologii, etnologii, teologii, ale najdeme zde i poznatky z dobové medicíny a biologie (Turóci, 2015: 22; Nagy, 2017: 5-18). V rámci historie je pak třeba rozlišovat také dílčí disciplíny jako jsou historická geografie, environmentální historie či regionální dějiny, pro něž Vědomosti představují jeden z klíčových pramenů.

Stranou zájmu odborné veřejnosti však prozatím stál didaktický potenciál Védomostí a pozornost dosud nebyla věnována otázce využití kritických edic Védomostí, případně i jejich latinských originálů, v rámci terciárního vzdělávání v oboru historie. Základem následujícího textu je tedy myšlenka propojení teoretických východisek vysokoškolské pedagogiky s metodickými postupy historické vědy. Na konkrétních př́kladech využití Belových Védomostí při vysokoškolské výuce historie nastíním další, dosud nezmapovaný, rozměr interpretace Belova díla, tentokrát však jako součást oboru pedagogika, respektive didaktika vysoké školy.

Text je založen na poznatcích $\mathrm{z}$ výuky na Katedře historických věd a středoevropských studií Filozofické fakulty Univerzity sv. Cyrila a Metoda v Trnavě (SR), kde jsou posluchači vzděláváni v jednooborovém studijním programu Historie a aplikovaná historie v kyberprostoru a také dvouoborovém studiu Učitelství akademických předmětů (historie v kombinaci). Obě studia jsou nabízena v bakalářském i magisterském stupni. Nedílnou součástí kurikula obou programů je předmět regionální dějiny (magisterský stupeň). Studenti jednooborového studia navíc na bakalářském stupni povinně absolvují předmět historická geografie a následně v magisterském studiu mohou navštěvovat kurz s názvem Dějiny environmentálního myšlení.

$\mathrm{V}$ př́spěvku nejprve ve stručnosti představím kontexty obecné vysokoškolské didaktiky, které následně aplikuji na vzdělávací standardy studia historie s důrazem na zvládnutí metodiky historické práce a profil absolventa. Obě roviny pak propojím v praktické části textu na ukázkách vybraných aktivit a prací studentů Katedry historických věd a středoevropských studií.

\section{Cíle vysokoškolského vzdělávání se zřetelem na studium historie}

Odborná pedagogická literatura zaměřená na vysokoškolskou didaktiku ve všeobecnosti definuje výchovně-vzdělávací cíle, jež systematizoval Benjamin Bloom. Cíle jsou manifestovány ve třech základních rovinách - kognitivní, afektivní a psychomotorické (Slavík et al., 2012: 24-25). Slovenská pedagožka T. Seben Zatkova pak hovoří o ,konkretizovaných všeobecných cilech vzděláváni", přičemž je řadí pod „specifické cille“ složek systému vysokoškolské výuky (Seben Zatková, 2014: 34). Dalším termínem, který je v souvislosti s cíli výuky uváděn, jsou „vzdělávaci standardy“, př́ípadně 
„výkonové a obsahové standardy“, v nichž se, podle Viliama Kratochvíla, „vzdělávací cíle zaměřjui na jádrové oblasti“, přičemž se „exemplárně konkretizuji““, a to formou ,kompetenčních požadavkü“. Тy „stanovují, jakými kompetencemi musí student disponovat v určité etapě studia, aby bylo možné považovat důležité cíle univerzitniho vzdělávání za dosažené". „Kompetenční požadavky“ se proměňují a jsou odstupňovány v souladu s narůstající náročností průběhu studia. Kompetence v tomto kontextu znamenají konkrétní a specifické „,výkonové dispozice“, kdy student získává schopnost mobilizace těchto způsobilostí ,, $v$ různých kontextech a činnostech systémů vědomostí, dovedností, schopností, sociálních a kulturních hodnot apod. " (Kratochvil, 2013: 63-64).

V rovině vysokoškolské prrípravy adeptů historické vědy bychom si výše uvedené obecné definice mohli přeložit jako postupné kroky k naplnění profilu absolventa studijního oboru historie. Vzdělávací standardy jsou úzce propojeny právě s požadavky na znalosti, schopnosti a dovednosti studentů, z nichž klíčovou roli hraje především správné zvládnutí metodiky historického výzkumu, jehož základem je práce s pramenným materiálem (Holec, 2013: 23-46).

Aktuální profil absolventa historie na Katedře historických věd a středoevropských studií FF UCM klade důraz na zvládnutí jak teoretické základny oboru, kterou tvoří, vedle poznatků z propedeutických historických disciplín a znalostí rozhodujících mezníků a kontextů vývoje lidské společnosti od pravěku do konce 20. století, tak na interdisciplinaritu. Katedra se orientuje na integrovaný přístup ke studiu historické vědy, což se odráží i ve skladbě nabízených kurzů, mezi nimiž jsou výrazné právě přednášky a semináře $z$ historické geografie, environmentální historie či regionálních dějin. Studenti se seznamují také se základy aplikované vědy, kdy se učí pracovat s geografickým informačním systémem či grafickými programy. Absolvent oboru historie tedy dokáže analyzovat a korektně interpretovat historické prameny, přičemž umí využívat široké portfolio metodických př́istupů. Postupné zvyšování nároků na studenty je podmíněno paralelním rozvíjením jejich osobnostní stránky, a to přiměřeně věku, schopnostem a stupni studia. Zde tedy můžeme hovořit o již zmíněných „kompetenčních požadavcích“ (Portal VŠ, 2019). V rámci posluchačů učitelského studia historie (v kombinaci s dalším oborem) jsou uvedené zásady přizpůsobeny specifikům dvouoborového studia, avšak zvláště zvolí-li si student jako svůj profilační obor historii (závěrečnou práci píše na Katedře historických věd a středoevropských studií), jsou aplikovány analogicky.

\section{Metodika historické vědy, didaktické metody a jejich aplikace na práci s Vĕdomostmi}

Základní metodické postupy $\mathrm{v}$ rámci práce historika, které jsou tradičně rozdělovány do čtyř fází, v sobě spojují teoretický i praktický aspekt odborného historického výzkumu. Jedná se o heuristiku, kritiku, interpretaci a syntézu (Buzek, 1994: 27). Jejich úspěšné zvládnutí je jednou z hlavních náplní vysokoškolského studia, přičemž je úzce propojeno s důrazem na výsledné zpracování výzkumu v podobě koherentního a odborně korektního 
textu, a to formou seminárních prací, prací studentské vědecké a odborné činnosti (SVOČ) i prací závěrečných.

Pokusíme-li se propojit metodiku historické vědy s principy obecné vysokoškolské didaktiky, nacházíme určité paralely, které dovolují oba př́stupy kombinovat. V rámci heuristiky a kritiky jsou to výzkumné (heuristické), respektive badatelské metody, jejichž jádrem je v obou disciplínách stanovení badatelské otázky či problému, na kterou je prostřednictvím další analýzy hledána odpověd' (Rohlikova - Vejvodova, 2012: 58-59).

Vědomosti Matěje Bela představují ideální učební materiál, který je možné využít při všech zmíněných etapách historikovy práce. Zejména kritické edice skýtají pro studenty zdroj ukázek hned několika typů výstupů. Jedná se o vědecké pramenné edice, tedy nejvyšší možné zpřístupnění pramene, jejichž nedílnou součástí jsou úvodní analytické stati, jež pramen zasazují do širokých souvislostí a mohou obsahovat také podrobný životopis Matěje Bela akcentující jeho přínos pro uherskou (slovenskou) historiografii, ale také geografii či filologii a další př́ibuzné disciplíny (Turoci, 2015: 15-24; Juríková, 2016: 16-32). Zásadní je ovšem fakt, že studenti pracují bezprostředně s pramenem, který je navíc k dispozici v latinském originále a zrcadlově ve slovenském překladu. To činí text dostupný i úplným začátečníkům, kteří by se po jazykové stránce s dobovou podobou textu jen těžko vyrovnávali. Pro pokročilejší studenty ale mohou edice představovat $\mathrm{i}$ jakýsi odrazový můstek, díky kterému se odhodlají pracovat také s originály

Belovych textů. Edice jim dají bezpečný základ pro orientaci v obsahové skladbě Vědomostí, slovenský překlad může v některých ohledech poskytnout analogickou slovní zásobu a terminologii, která se objevuje např́ič všemi exempláři Vědomostí.

V rámci kurzů na Katedře historických věd a středoevropských studií vyučuje problematiku regionálních dějin, historické geografie a environmentální historie prof. RNDr. Peter Chrastina, PhD., autor odborných statí na téma interpretace díla Matěje Bela (Chrastina - Racova, 2015, 2016; Chrastina, 2019a, 2019b). Jeho metodické postupy se odrážejí také v tom, jak jsou studenti vedeni při práci s texty Vědomostí, a to od prvotního vytyčení badatelské otázky, přes práci s kartografickými podklady, až k historickogeografické interpretaci získaných dat a jejich písemnému zpracování.

Jedním z př́kladů ideálního didaktického, a zároveň historicko-metodického, postupu je model, kdy student dostane za úkol zvolit si konkrétní obec popsanou Belem. Pokud jde o obec, která je nějakým způsobem pro studenta blízká, je didaktický aspekt obohacen o významný motivační rámec, který má z pedagogického pohledu silný aktivizační potenciál. Student na bakalářském stupni nejprve na př́kladu obce zjištuje, jak její popis ve Vědomostech odpovídá aktuální podobě obce. K tomu je zapotřebí práce nejen bezprostředně s pramenem, ale student se musí naučit věnovat pozornost kompletní heuristice, což v intencích historické vědy znamená shromáždění všech dalších dostupných pramenů a literatury. Typicky jsou to monografie o dané obci, stati v periodikách, sbornících či další výstupy v rozličných regionálně zaměřených titulech. Podle potřeby je možné teoretické bádání doplnit o poznatky $\mathrm{z}$ terénu, pořídit fotodokumentaci, provést etnografické 
šetření. Posluchači se tímto způsobem nejen seznamují se základy historického výzkumu, ale učí se také pracovat v rámci určitého časového a organizačního harmonogramu.

Ti ze studentů, kteří téma rozvíjejí např́íklad do podoby práce SVOČ, nebo později do bakalářské práce, postupně pracují nejen s edicí Vědomostí, ale $\mathrm{v}$ rámci heuristiky a kritiky vyhledávají širší okruh pramenného materiálu, kterým mohou být urbáře, matriky nebo obecní kroniky. Analýza takových typů pramenů však již zpravidla vyžaduje alespoň základní znalosti paleografie a dalších cizích jazyků (latinský jazyk, mad’arský jazyk).

Právě v postupné gradaci obtí̌nosti tkví univerzálnost využití Belových Védomostí jakožto didaktické pomůcky i ryze odborného textu zároveň. Neméně významnou je i interdisciplinární rovina tohoto pramene. $\mathrm{V}$ rámci jeho interpretace lze demonstrovat metodické postupy dalších či př́buzných vědních disciplín, které korespondují i s obsahovou náplní vyučovaných kurzů (historická geografie, environmentální dějiny, regionální dějiny, jsou zde patrné přesahy do hospodářských dějiny či historické antropologie). Zajímavým prvkem je využití kartografických podkladů, kdy studenti přenášejí do slepé mapy krajinné prvky i různé významné lokality tak, jak je zachytil Bel.

Obecně didaktický aspekt je opakovaně naplňován prostřednictvím zvládnutí heuristických metod tak, jak jsou definovány vodborné pedagogické literatuře. Při závěrečném syntetizování výsledků vlastního bádání se pak student učí nejen správně používat odbornou historickou terminologii, ale také tříbí své vyjadřovací schopnosti. $Z$ pohledu všeobecné didaktiky tyto postupy můžeme definovat jako dílčí součásti „samostatné práce“ č̌i „,kompozice (seminární práce)“, respektive tvorby textu (Rohlikova Vejvodova, 2012: 57-65).

\section{Obrázek 1: Zvolenská stolice, ukázka textu edice (Bel, 2017: 58-59)}

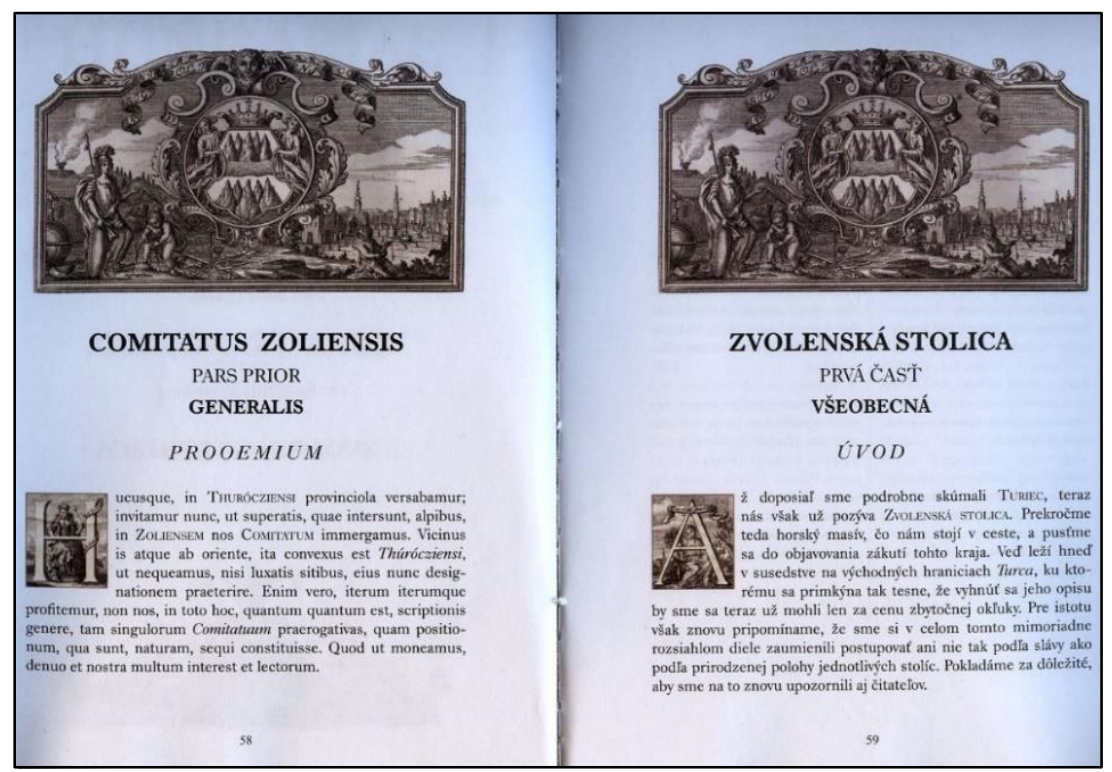

Slavonic Pedagogical Studies Journal, eISSN 1339-9055, ISSN 1339-8660, Volume 9 Issue 1, 2020 


\section{Př́klady studentských prací využívajících Belovy Vědomosti}

Následující př́íklady vycházejí z konkrétních studentských prací, které byly realizovány na Katedře historických věd a středoevropských studií FF UCM. Jde o výstupy demonstrující využití kartografického materiálu a náčrt obsahu magisterské práce věnované vybraným obcím z regionu Liptov (Liptovská stolice).

Př́klad č. 1: práce se slepou mapou

Posluchači jednooborového studia, studijního programu Historie a aplikované historie v kyberprostoru, v rámci magisterského kurzu Dějiny environmentálního myšlení využívají edice Belových Vědomostí jako výchozího textu pro doplňování údajů do upravené slepé mapy. Na základě informací ve Vědomostech zachycují základní charakteristiku vybrané stolice (obr. č. 1), přičemž se seznamují s kartografickými znaky, které se učí používat. I $\mathrm{v}$ těchto zdánlivých drobnostech tkví důležitý rozměr interdisciplinární intepretace Vědomostí a její následná aplikace do praktické výuky adeptů historické vědy (Chrastina, 2010: 121-127).

Obrázek 2: Ukázka slepé mapy: Turčanská stolice pohledem Matěje Bela.

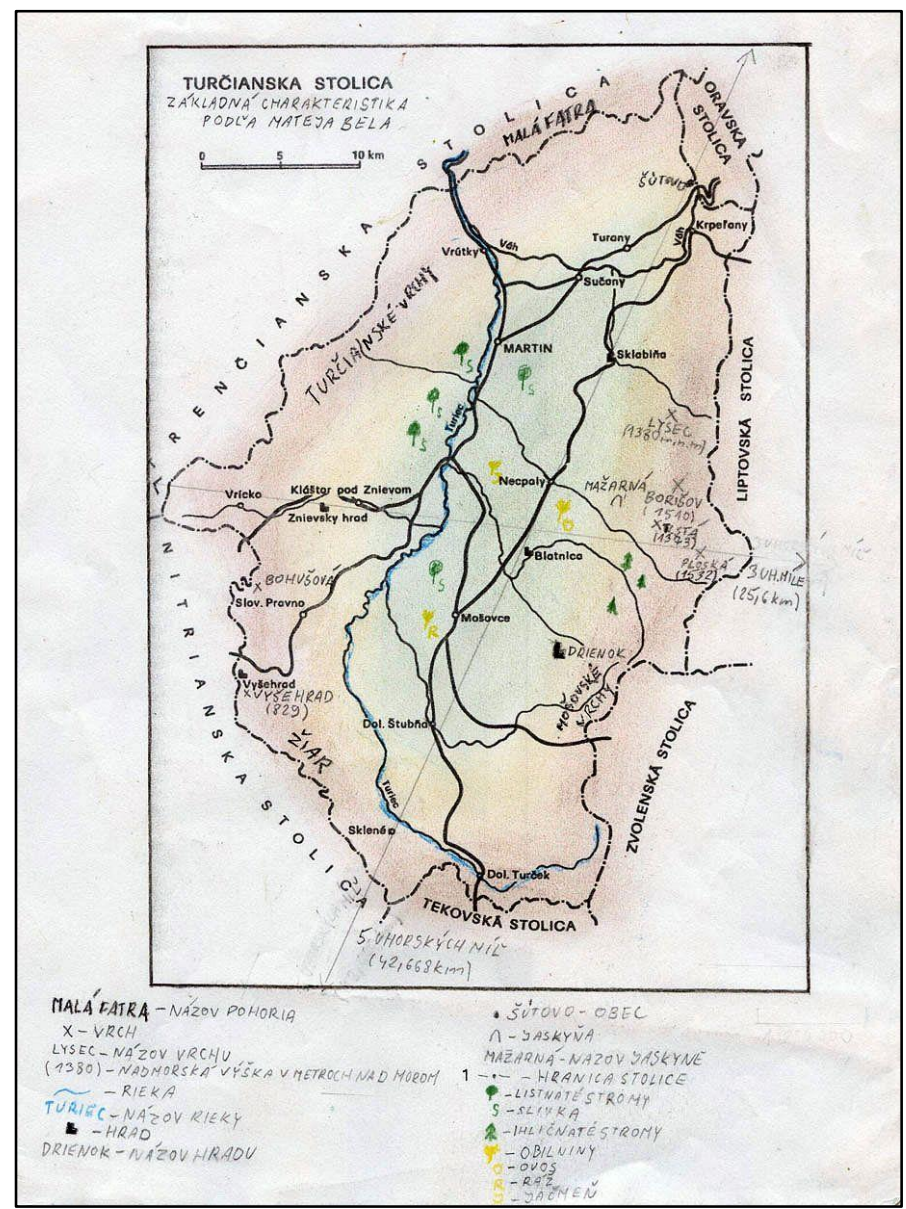


Druhá mapa (obrázek 3) zachycuje pěstování zemědělských plodin (luštěniny, obiloviny) a chov hospodářských zviřat (skot, koně, prasata, ovce) na území Oravské stolice $\mathrm{v}$ souladu $\mathrm{s}$ charakteristikou této stolice ve Vědomostech.

Oba uvedené př́íklady práce $\mathrm{s}$ mapou, spolu $\mathrm{s}$ další analýzou a pramene, inspirují studenty $\mathrm{k}$ přemýšlení o podobách krajin $\mathrm{v}$ minulosti a dnes, a také nad jejich dobovým vnímáním. V této fázi analýzy Védomostí je předobrazem interpretace textu koncept „vyprávěné krajiny“, jak jej charakterizuje Eva Semotanova (2018: 11-19).

Obrázek 3: Ukázka slepé mapy: Zemědělské plodiny a chov dobytka v Oravské stolici pohledem Matěje Bela.

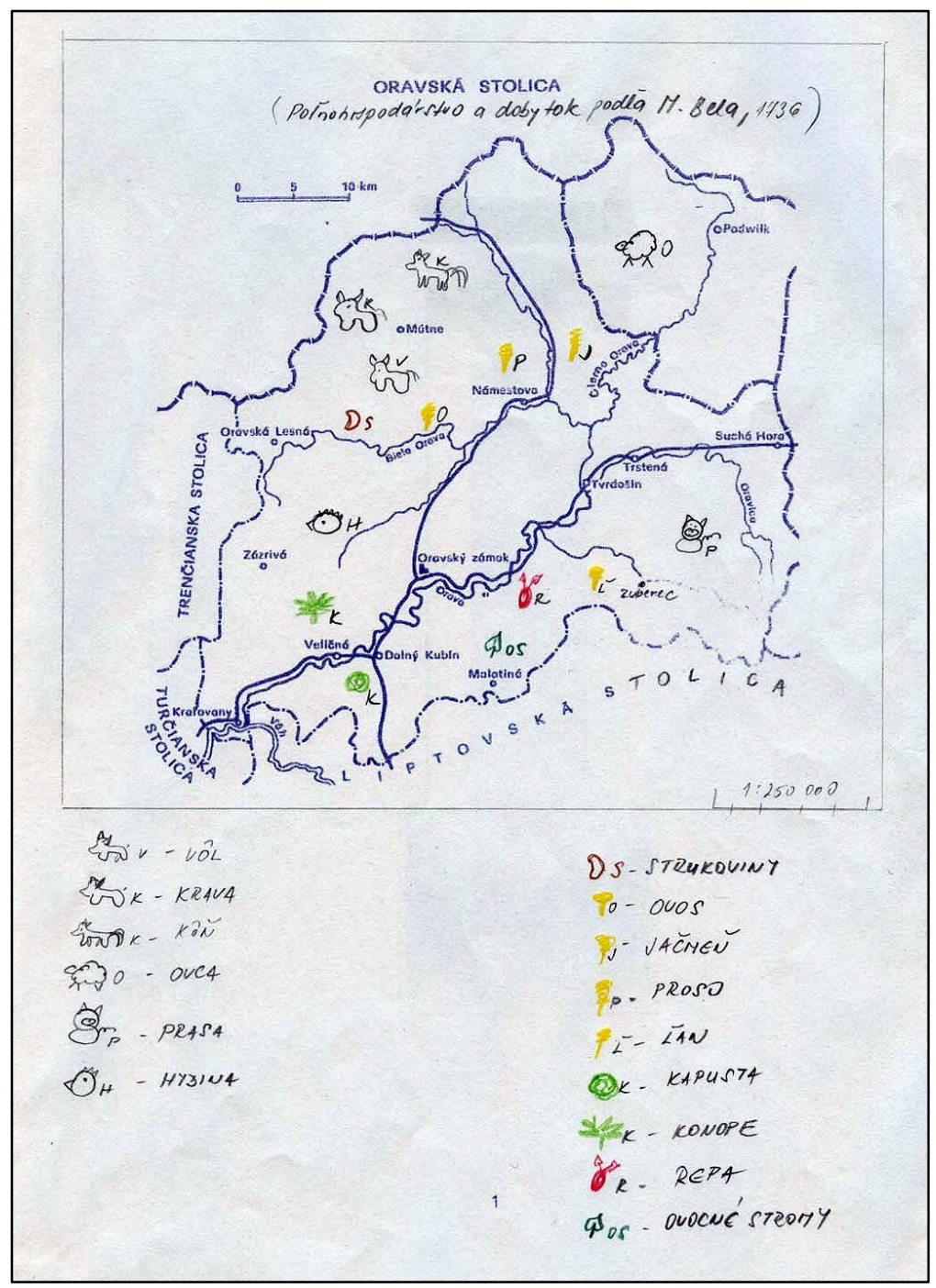




\section{Poděkování}

Text vznikl v rámci projektů KEGA-005UCM-4/2019 Prírodné pomery Nitrianskej stolice v 18. storočí pohl'adom Mateja Bela (vysokoškolská učebnica) a APVV-18-0196 Vedomosti Nitrianskej stolice M. Bela (interpretácia a aplikácia) na Katedře historických věd a středoevropských studií Filozofické fakulty Univerzity sv. Cyrila a Metoděje v Trnavě.

\section{Bibliographic references}

BEL, M. 2015. Oravska stolica. Cadca: Kysucke muzeum v Cadci. ISBN 978-80-89751-10-5.

BEL, M. 2016. Turcianska stolica. Cadca: Kysucke muzeum v Cadci. ISBN 978-80-89751-15-0.

BEL, M. 2017. Zvolenska stolica. Cadca: Kysucke muzeum v Cadci. ISBN 978-80-89751-17-4.

BEL, M. 2019. Tekovska stolica. Cadca: Kysucke muzeum v Cadci. ISBN 978-80-88708-66-7.

BUZEK, V. et al. 1994. Uvod do studia historie. Ceské Budejovice: Pedagogicka fakulta JU. ISBN 80-7040-063-3.

HAJAS, J. 2018. Vybrane lokality Liptovskej stolice pohladom Mateja Bela (diplomova praca). Trnava: Univerzita sv. Cyrila a Metoda v Trnave.

HOLEC, R. 2013. Metodika a technika historikovej prace. Ako sa pracuje s pramenmi? In: Dejiny, n. 1, pp. 23-46. ISSN 1337-0707.

CHRASTINA, P. 2010. Mapy v historickom vyskume: vyznam, interpretacia, limity. In: FERIANCOVA, A. - GLEJTEK, M., eds. Pramen jeho funkcia, vyznam, interpretacia a limity v historickom vyskume. Nitra: Univerzita Konstantina Filozofa v Nitre, pp. 121-127. ISBN 978-80-8094587-9.

CHRASTINA P. - RACOVA, K. 2015. Mosty na uzemi Nitrianskej stolice v prvej polovici 18. storocia podla Mateja Bela (historicko-geograficky pristup). In: Studia Historica Nitriensia, vol. 19, n. 1, pp. 160-165. ISSN 1338-7219.

CHRASTINA P. - RACOVA, K. 2016. Dudvah pohladom Mateja Bela. In: Geographical information, vol. 20, n. 2, pp. 494-506. ISSN 1337-9453.

CHRASTINA, P. 2019a. Nerudne suroviny Nitrianskej stolice pohladom Mateja Bela. In: Studia Historica Nitriensia, vol. 23, n. 1, pp. 29-42. ISSN 1338-7219.

CHRASTINA, P. 2019b. Jaskyna Certova pec vo Vedomostiach Nitrianskej stolice Mateja Bela. In: Historicka geografie, vol. 45, n. 1, pp. 139-154. ISSN 0323-0988.

JURIKOVÁ, E. 2016. Velky zemepisno-historicky projekt Mateja Bela. In: BEL, M. 2016. Turcianská stolica. Cadca: Kysucke muzeum v Cadci, pp. 1632. ISBN 978-80-89751-15-0.

KRATOCHVIL, V. 2013. Moznosti vymedzovania a rozvijania predmetovych kompetencii studentov historie v ucitelskom studiu. In: Dejiny, n. 1, pp. 63-64. ISSN 1337-0707.

NAGY, I. 2017. Cicavce vo Vedomostiach Mateja Bela. In: Quaestiones rerum naturalium 4, n. 2, pp. 5-18. ISSN 1339-7907. 
PORTALVS.SK Filozoficka fakulta UCM [cit. 2019-12-16]. Available online: https://www.portalvs.sk/sk/fakulta/filozoficka-fakulta4

ROHLIKOVA, L. - VEJVODOVA, J. 2012. Vyucovací metody na vysoke skole. Praha: Grada. ISBN 978-80-247-4152-9.

SEMOTANOVA, E. 2018. Vypravene krajiny. Praha: Historicky ustav AV CR. ISBN 978-80-7286-330-3.

SLAVIK, M. et al. 2012. Vysokoskolska pedagogika. Praha: Grada. ISBN 978-80-247-4054-6.

SEBEN ZATKOVA, T. 2014. Uvod do vysokoskolskej pedagogiky. Trnava: Univerzita sv. Cyrila a Metoda v Trnave. ISBN 978-80-8105-611-6.

TUROCI, M. 2015. Zivot a dielo Mateja Bela. In: BEL, M. 2015. Oravska stolica. Cadca: Kysucke muzeum v Cadci, 22 p. ISBN 978-80-89751-10-5.

Mgr. Tatána Součková, PhD.

Department of Historical sciences and Central European Studies

Faculty of Arts

University of Ss. Cyril and Methodius

Nám J. Herdu 2

91701 Trnava

Slovak Republic

tatana.souckova@ucm.sk 